\title{
Minodronate for the treatment of osteoporosis
}

This article was published in the following Dove Press journal:

Therapeutics and Clinical Risk Management

\author{
Tsuyoshi Ohishi' \\ Yukihiro Matsuyama² \\ 'Department of Orthopaedic Surgery, \\ Enshu Hospital, Hamamatsu, Shizuoka, \\ Japan; ${ }^{2}$ Department of Orthopaedic \\ Surgery, Hamamatsu University School \\ of Medicine, Hamamatsu, Shizuoka, \\ Japan
}

\begin{abstract}
Minodronate is a third-generation bisphosphonate that was developed and approved for clinical use in osteoporosis therapy in Japan. The mechanism of action for suppressing bone resorption is the inhibition of farnesyl pyrophosphate synthase, a key enzyme in the mevalonic acid metabolic pathway of osteoclasts, to induce apoptosis of the cells. Minodronate is the strongest inhibitor of bone resorption among the currently available oral bisphosphonates. Large randomized, placebo-controlled, double-blind clinical trials have revealed an increase in bone mineral density of both the lumbar spine and femoral neck over 3 years of daily minodronate therapy and risk reduction in vertebral fractures over 2 years of therapy. The increase in bone mass and the prevention of vertebral fractures are similar to those with alendronate or risedronate. The incidence of adverse events, especially gastrointestinal disturbance, is the same as or less than that with weekly or daily alendronate or risedronate. The unique mechanism of action of minodronate via the inhibition of the $\mathrm{P} 2 \mathrm{X}(2 / 3)$ receptor compared with other bisphosphonates may be an advantage in reducing low back pain in patients with osteoporosis. The monthly regimen of minodronate, introduced in 2011, is expected to have better patient adherence and longer persistence. In experimental animal models, minodronate preserved, or even ameliorated, bone microarchitectures, including microcracks and perforation of the trabeculae in the short term. The lowest incidence of bisphosphonate-related osteonecrosis of the jaw among all bisphosphonates and the lack of atypical femoral fractures attributed to its use to date, however, are partly because only a smaller population used minodronate than those using other bisphosphonates. To date, minodronate is available only in Japan. Hip fracture risk reduction has not been verified yet. More clinical studies on minodronate and its use in osteoporosis treatment, with a large number of subjects, should be conducted to verify hip fracture risk reduction and long-term results.

Keywords: bisphosphonate, bone mineral density, fracture, minodronate, osteoporosis, farnesyl pyrophosphate synthase, zoledronate, bone marker, bone quality, clinical trial, long-term therapy, pain reduction
\end{abstract}

\section{Plain language summary}

As we get older, our bones become weaker. This process is known as osteoporosis. Technically, it is a skeletal disorder characterized by decreasing bone mass, loss of normal bone structure, and increasing risk of broken bones (fractures). Patients with osteoporosis commonly have fractures of their hips and back (vertebral) bones. Those who suffer from hip fractures might require long-term care, similar to those who suffer from a stroke. The main treatment for osteoporosis is medication. Among various anti-osteoporosis drugs, minodronate, which was developed in Japan, belongs to the class of drugs called bisphosphonates and is the strongest suppressor of bone resorption. The usefulness of minodronate in osteoporosis treatment is not yet known globally because, unfortunately, to date, it is available only in Japan. According to a 2-year study, minodronate is very effective for vertebral fracture prevention. Furthermore, patients take it more reliably and for a longer period because of its monthly regimen, compared with the weekly regimen of other bisphosphonates. We expect that patients with osteoporosis will need long-term therapy. In this review, we showed the effectiveness of minodronate therapy
Correspondence: Tsuyoshi Ohishi Department of Orthopaedic Surgery, Enshu Hospital, I-I Chuo I-chome, Naka-ku, Hamamatsu, Shizuoka 430 0929, Japan

$\mathrm{Tel}+8 \mathrm{I} 53453$ IIII

Fax +8I 53401008 I

Email t-ohishi@ken.ja-shizuoka.or.jp
Therapeutics and Clinical Risk Management 2018:14 729-739

729

submit your manuscript $\mid$ www.dovepress.com

Dovepress if in 0

http://dx.doi.org/10.2147/TCRM.S149236 (c) (1) (5) 2018 Ohishi and Matsuyama. This work is published and licensed by Dove Medical Press Limited. The full terms of this license are available at https://www.dovepress.com/terms.php cc) and incorporate the Creative Commons Attribution - Non Commercial (unported, v3.0) License (http://creativecommons.org/licenses/by-nd/3.0/). By accessing the work you hereby accept the Terms. Non-commercial uses of the work are permitted without any further permission from Dove Medical Press Limited, provided the work is properly attributed. For permission for commercial use of this work, please see paragraphs 4.2 and 5 of our Terms (https://www.dovepress.com/terms.php). 
in patients with osteoporosis and discussed the issues that need to be solved in the future.

\section{Introduction}

Osteoporosis is a skeletal disorder characterized by susceptibility to fractures owing to decreased bone mineral density (BMD) and deterioration of bone microarchitecture. ${ }^{1}$ With the growing number of aging individuals, the number of patients with osteoporosis is expected to increase. In Japan, the prevalence of osteoporosis was 3.4\% among men and $19.2 \%$ among women, upon evaluation by lumbar spine BMD, and it was $12.4 \%$ for men and $26.5 \%$ for women, upon evaluation by femoral neck BMD, among the general population aged $\geq 40$ years. $^{2}$ The prevalence of existing osteoporotic vertebral fractures in Japanese women aged $\geq 65$ years was the highest (24\%-28\%) among the population of the Asian countries studied. ${ }^{3,4}$ Hip fracture is one of the most devastating complications of osteoporosis, which results in severe morbidity, decreased quality of life, and even high rates of mortality. ${ }^{5-7}$ Unfortunately, a recent report indicated that the incidence of hip fractures in both men and women was still increasing in Japan from 2009 to $2014 .{ }^{8}$ However, it showed declining trends after 1990-2000 worldwide, especially in North America, Europe, and Oceania. ${ }^{9}$ This declining trend was partly due to the increased numbers of the patients who were prescribed with anti-osteoporosis drugs. ${ }^{10,11}$ Raising prescription rates of anti-osteoporosis medications is an urgent issue in Japan. Currently, several anti-osteoporosis drugs are available. Among those, bisphosphonates such as alendronate and risedronate are the first-line drugs for osteoporosis therapy because of their strong efficacy for vertebral and hip fracture prevention. ${ }^{12-15}$ Bisphosphonates have several advantages over other anti-osteoporosis drugs in addition to the efficacy for fracture prevention and increasing bone mass. Specifically, they have alternatives for medication dosing frequency due to their nature of longterm accumulation in the bone. Physicians can select daily, weekly, monthly, or even yearly regimens depending on the patient's preference to improve adherence and persistence. Enhancing adherence and persistence with bisphosphonates reduced the risk of fractures and could assist with costeffectiveness. ${ }^{16,17}$ Minodronate, which was developed and approved for osteoporosis treatment in Japan, is categorized as a third-generation bisphosphonate. ${ }^{18}$ First, the daily regimen ( $1 \mathrm{mg} /$ day) was developed and came onto the market in 2009; this was followed by the monthly regimen $(50 \mathrm{mg} /$ every 4 weeks) in 2011. Publications on minodronate for osteoporosis therapy are still scarce because minodronate has been limited to use only in Japan (Table 1). To date, 2 review articles on minodronate in the treatment of osteoporosis were published in the English literatures. ${ }^{19,20}$ The aim of this article was to review the clinical efficacy of minodronate for osteoporosis therapy, adding most recent publications on previous review articles.

\section{Structure of minodronate}

Bisphosphonates have a $\mathrm{P}-\mathrm{C}-\mathrm{P}$ bond as their basic structure, with R1 and R2 side chains, and are divided into 3 groups according to variations in the R2 side chains. ${ }^{21}$ Minodronate is categorized as a third-generation bisphosphonate. First-generation bisphosphonates, such as etidronate and clodronate, do not include nitrogen in the R2 side chain. Second-generation bisphosphonates, such as alendronate, ibandronate, and pamidronate, have an alkyl amine with nitrogen in the R2 side chain. Third-generation bisphosphonates, including risedronate, zoledronate, and minodronate, have aromatic rings with nitrogen. The mechanisms for the inhibition of osteoclast function differ between the first (non-nitrogen-containing) and second/third generations (nitrogen-containing). First-generation bisphosphonates convert themselves into ATP analogs after being metabolized in the osteoclasts and induce osteoclast apoptosis; however, nitrogen-containing bisphosphonates inhibit farnesyl pyrophosphate synthase (FPPS) in the mevalonic acid metabolic pathway in osteoclasts so that osteoclasts can be inactive and induce osteoclast apoptosis. ${ }^{22}$ The order of the power of inhibition of FPPS is clodronate $<$ etidronate $<$ pamidronate $<$ alendronate $<$ ibandronate $<$ risedronate $<$ minodronate $=$ zoledronate. ${ }^{23}$ Among the oral bisphosphonates, minodronate is the strongest inhibitor of bone resorption; zoledronate is currently available only as an intravenous injection. Minodronate is 10,000 times more active for the inhibition of bone resorption than etidronate and 10-100 times more active than alendronate and risedronate. ${ }^{23}$ Conversely, regarding the affinity to hydroxyapatite, minodronate has a moderate affinity compared with all bisphosphonates, which is lower than that of zoledronate. Low-affinity bisphosphonates, such as risedronate, have weaker uptake and are more diffused to the appendicular bone. ${ }^{24-27}$ In contrast, higher affinity bisphosphonates, such as alendronate, have avid uptake to bone, but are less diffused. Faster reduction of nonvertebral fractures is expected for low-affinity bisphosphonates because of wider and quicker distribution to the bone. ${ }^{25}$ Minodronate, which suppresses bone resorption strongly and has moderate affinity to the bone, is expected to reduce not only vertebral fracture risk, but also nonvertebral fracture risk, especially 


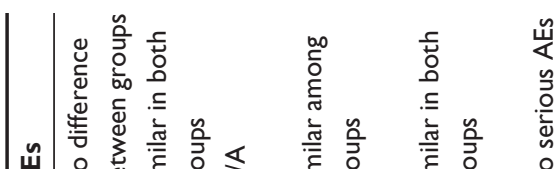

岃

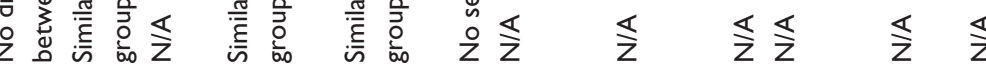

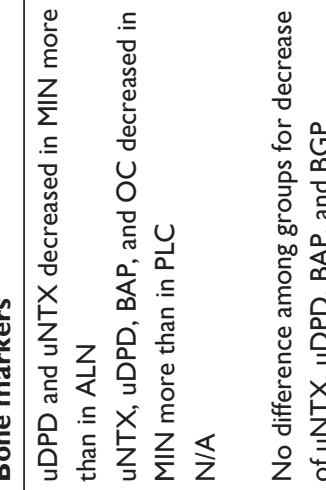

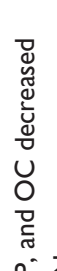

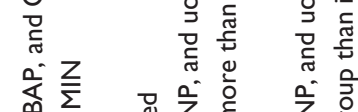

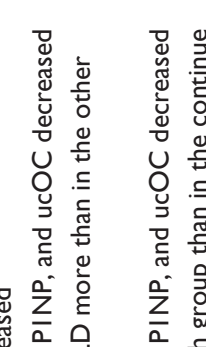

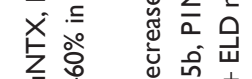

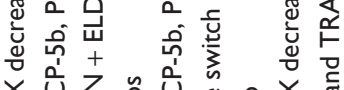

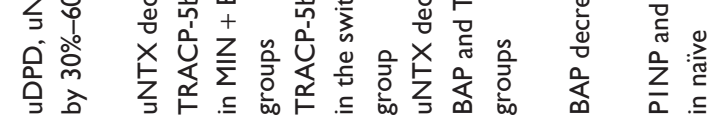

동

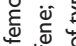

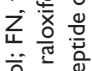

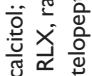

훙

S.

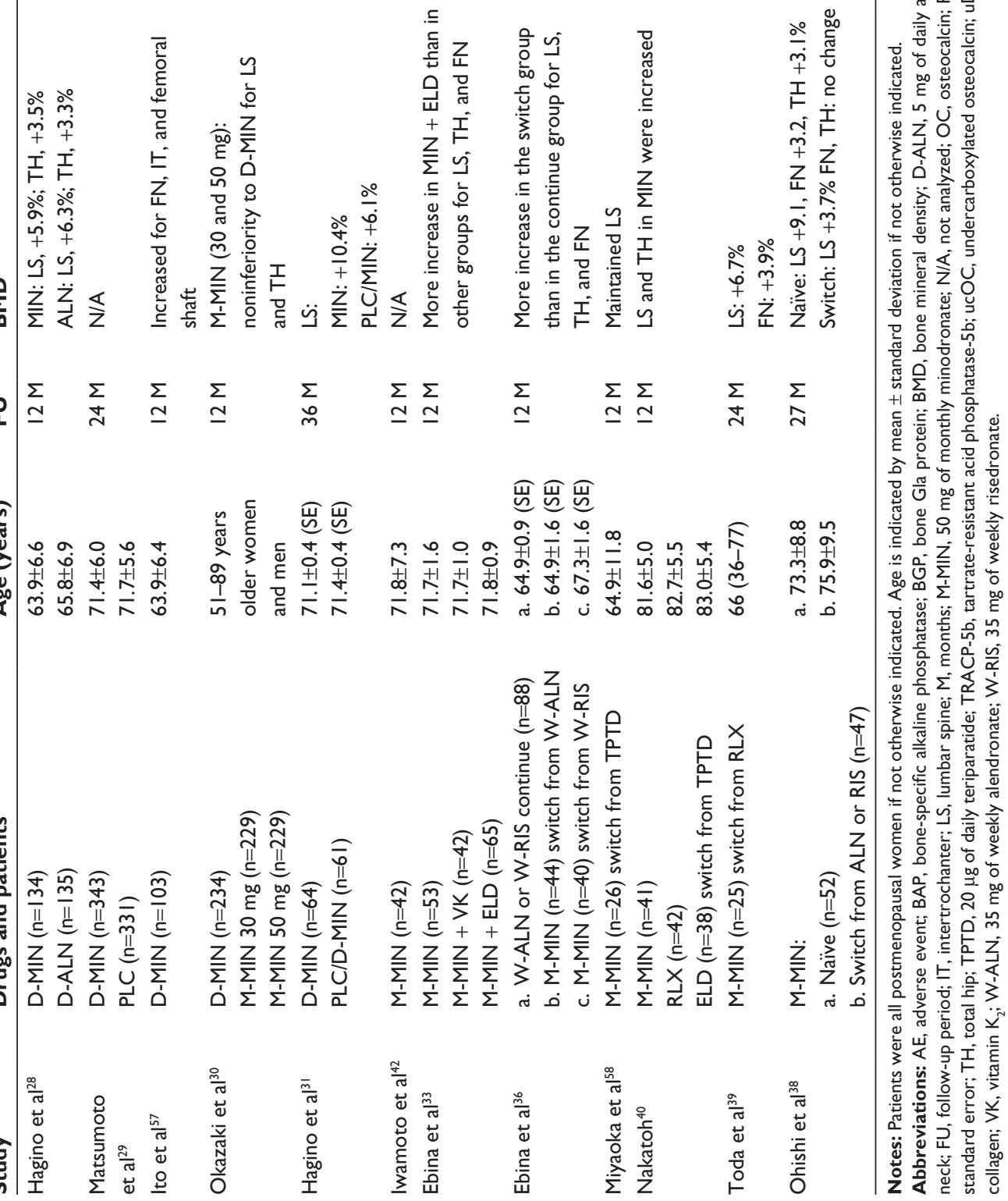


hip fracture risk. Unfortunately, hip fracture risk reduction for minodronate has not yet been verified.

\section{Randomized, double-blind, clinical trials of minodronate for osteoporosis}

The first study to demonstrate the efficacy of minodronate for patients with osteoporosis was reported in $2009 .{ }^{28}$ The efficacy and safety of minodronate were examined by direct comparison with alendronate in a randomized, active-controlled, double-blind, multicenter study. Minodronate (1 mg/day) and alendronate ( $5 \mathrm{mg}$ /day) were administered daily to the patients with osteoporosis in the minodronate group $(n=135)$ and alendronate group $(n=135)$ for 12 months. All patients were aged $\geq 45$ years and either had a BMD $<70 \%$ or a $T$-score of -2.6 of the young adult mean (YAM) or had osteopenia (a BMD $<80 \%$ or $T$-score of -1.7 of the YAM) with at least 1 fragility fracture. A daily supplement of calcium was administered to all subjects. The lumbar spine BMD increased by $5.86 \%$ and $6.29 \%$ in the minodronate and alendronate groups, respectively, and the total hip BMD increased by $3.47 \%$ and $3.27 \%$ in the minodronate and alendronate groups, respectively. Bone resorption markers, including urinary deoxypyridinoline and N-terminal telopeptide of type I collagen (NTX), decreased more in the minodronate group than in the alendronate group. The overall incidence of adverse events, including gastrointestinal disturbance, was similar between the groups. Noninferiority of minodronate to alendronate in terms of BMD increase, suppression of bone resorption, and the incidence of adverse events was observed.

A phase III trial with minodronate was conducted in a randomized, double-blind, placebo-controlled, multicenter study to examine the efficacy of daily minodronate for the prevention of vertebral fractures at 24 months in 704 postmenopausal women with established osteoporosis. ${ }^{29}$ Postmenopausal women, aged 55-80 years, with 1-5 fragility vertebral fractures and $\mathrm{BMD}<80 \%$ ( $T$-score of -1.7 at the lumbar spine) of YAM, were divided into the minodronate group with 343 patients and the placebo group with 331 patients. Daily supplements of calcium and vitamin D were administered to all subjects. Minodronate, administered for 24 months, reduced the risk of vertebral fractures by $59 \%$ (95\% confidence interval, 36.6\%-73.3\%). No differences in adverse events, including gastrointestinal disturbance, were observed between the groups. Safety and efficacy of daily minodronate for vertebral fracture prevention for 2 years were confirmed.
Okazaki et $\mathrm{al}^{30}$ demonstrated similar efficacy of $50 \mathrm{mg}$ of monthly minodronate with a daily regimen of $1 \mathrm{mg}$ in terms of changes in BMDs, bone turnover markers, and frequency of adverse events by a randomized, double-blind, activecontrolled, parallel-group, multicenter study. The study included a total of 692 men and postmenopausal women (>96\% were women) with osteoporosis, aged 51-89 years, who had a BMD $<70 \%$ ( $T$-score of -2.6 at the lumbar spine) of YAM or a BMD $<80 \%$ ( $T$-score of -1.7 at the lumbar spine) of YAM with at least 1 fragility fracture. Different doses of minodronate (either 30 or $50 \mathrm{mg}$ monthly or a daily dose of $1 \mathrm{mg}$ ) were administered to the corresponding 3 groups; those were randomly assigned. Efficacy for the increase in the spine and total hip BMDs in the 30- or 50-mg monthly group was noninferior to those of the daily group. Changes in bone turnover markers and safety profiles were also comparable among groups.

The 3-year results of daily minodronate on BMD, bone turnover markers, incidence of vertebral fractures, and safety profile were reported by the 1-year extension study of the original 2-year phase III study. ${ }^{31}$ All participants, including those in the placebo group in the original 2-year study, took daily minodronate from the 24-month point. Lumbar spine BMD increased by $10.4 \%$ in the minodronate group $(n=64)$ and $6.1 \%$ in the placebo/minodronate group $(n=61)$ over 3 years. The bone turnover markers decreased steeply at 6 months and plateaued thereafter in the minodronate group, while, in the placebo/minodronate group, they decreased just after the initiation of minodronate at the 24-month point. The incidence of new vertebral fractures for 3 years was similar to that for the first 2 years. The incidence of adverse events, including gastrointestinal disturbance, was similar in the 2 groups. Neither bisphosphonate-related osteonecrosis of the jaw (BRONJ) nor atypical femoral fractures (AFFs) were reported.

Post hoc analysis of a 2-year phase III trial revealed that the numbers and severity of prevalent vertebral fractures were independent risk factors for the incidence of new vertebral fractures, and minodronate reduced the fracture risk. ${ }^{32}$ Daily minodronate reduced the relative risk for vertebral fractures by $45.2 \%, 61.1 \%$, and $64.2 \%$ for patients with 1,2 , and $\geq 3$ prevalent vertebral fractures, respectively, and $87.8 \%, 64.6 \%$, and $50.1 \%$ for patients with mild, moderate, and severe prevalent vertebral fractures, respectively. Due to the strong suppression of bone resorption for minodronate, the fracture risk could be reduced even in the patients at a higher risk of fracture. 


\section{Other clinical studies on minodronate Combination therapy}

Monthly minodronate combined with eldecalcitol $(0.75 \mu \mathrm{g} /$ day $)$ resulted in a greater increase of lumbar spine and hip BMDs and greater decrease of bone turnover markers than those observed in minodronate monotherapy at 12 months in 193 patients with osteoporosis (178 were women). ${ }^{33}$ A significant decrease in the serum $25-\mathrm{OH}$ vitamin $\mathrm{D}_{3}$ level, with a concomitant increase in the serum whole parathyroid hormone level, compared with the baseline values during short-term (4 months) daily minodronate monotherapy was reported. ${ }^{34}$ Taken together, combined therapy with vitamin $\mathrm{D}_{3}$, rather than minodronate monotherapy, may be more effective for increasing bone mass. Daily minodronate combined with weekly subcutaneous injection of 20 units of calcitonin increased the BMD of the spine and femoral neck more than with minodronate monotherapy for 6 months in 51 women with postmenopausal osteoporosis. ${ }^{35}$

\section{Switching to minodronate from other anti-osteoporosis drugs}

Several studies have shown that switching to minodronate from alendronate or risedronate increases BMD. Greater increase of BMDs of the lumbar spine, total hip, and femoral neck in postmenopausal women with rheumatoid arthritis was reported over 12 months when prior long-term weekly alendronate or risedronate was replaced by monthly minodronate (switch group) compared with those who continued prior alendronate or risedronate (continue group). ${ }^{36}$ Another study demonstrated that BMDs of the lumbar spine and distal radius were significantly increased at 6 months in the switch group compared with those in the continue group in 397 patients with osteoporosis ( $>90 \%$ were women). ${ }^{37}$ According to our study, a significant increase in the lumbar spine BMD at 27 months of monthly minodronate therapy, compared with the baseline value in the switch group, in 47 female patients with osteoporosis was observed. ${ }^{38}$ Because of the stronger efficacy for the inhibition of bone resorption of minodronate than that of alendronate or risedronate, more BMD gain is expected when alendronate or risedronate is replaced by minodronate. However, when enough remodeling space in the bone is not available for minodronate to exert its action because of prior bisphosphonate therapy, the BMD may not increase. Lumbar spine and femoral neck BMDs increased after switching over to minodronate from raloxifene in 27 postmenopausal women aged 66 years, who were unresponsive in terms of BMD to the prior $\geq 2$ years of raloxifene therapy. ${ }^{39}$ It might be more effective for BMD gain if minodronate replaced the anti-osteoporosis drugs that have a different mechanism of action from the bisphosphonates. In addition, minodronate can be the first-line drug for post-teriparatide therapy. Monthly minodronate or raloxifene for 12 months increased the BMDs of the lumbar spine and total hip after 2 years of daily teriparatide therapy in postmenopausal women. ${ }^{40}$ When the turnover rates were calculated from the changes in the bone formation marker (bone-specific alkaline phosphatase) and resorption marker (tartrate-resistant acid phosphatase-5b [TRACP-5b]) levels, formation-dominant bone turnover was maintained after daily teriparatide therapy when replaced by minodronate; however, it was resorption dominant when replaced by raloxifene at 12 months of treatment. Ongoing bone mass gain is expected with minodronate therapy rather than with raloxifene after teriparatide therapy.

\section{Minodronate for patients with hip fractures}

To date, only 1 paper examined the efficacy of minodronate on increasing BMD for patients with hip fractures. Ohishi et $\mathrm{al}^{41}$ investigated BMD changes after hip fracture by administering monthly minodronate over 9 months in 51 patients with a mean age of 82.0 years. Minodronate was administered within 3 months after hip fracture surgery. Lumbar spine BMD increased by $2.7 \%$ compared with the baseline values; however, femoral neck and total hip BMDs did not change significantly. Fracture-related adverse events, including nonunion or delayed union, were not encountered. The patients who were independently mobile prior to injury showed greater recovery of BMD in the hip region during the 9 months of treatment.

\section{Treatment preference and persistence for monthly minodronate}

After $50 \mathrm{mg}$ of monthly minodronate was approved for clinical use, advantages of monthly minodronate over weekly bisphosphonates were reported. Treatment preference and persistence of monthly minodronate among patients with osteoporosis, aged an average of 76.0 years, who were being treated with daily or weekly bisphosphonates, were investigated. ${ }^{37}$ Two hundred and sixty-four patients were allocated to the switch group, those switched over to monthly 
minodronate from weekly alendronate or risedronate, and 133 patients were allocated to the continue group, those who continued their current therapy. Persistence of treatment in the switch group $(89.8 \%)$ was significantly higher than in the continue group (78.9\%) over 6 months. Preference of the monthly regimen over the weekly regimen was further confirmed by a crossover study conducted by Iwamoto et al. ${ }^{42}$ One hundred and fifteen patients with osteoporosis were randomly divided into 2 groups: 1 group received monthly minodronate for 3 months, followed by weekly alendronate or risedronate for another 3 months, and the other group received weekly alendronate or risedronate for 3 months, followed by monthly minodronate for another 3 months. More patients preferred the monthly minodronate $(65.2 \%)$ than the weekly bisphosphonate (15.7\%). Furthermore, more patients found the monthly regimen to be more convenient $(73.0 \%)$ than the weekly regimen (13.9\%). According to Ebina et al, $80.8 \%$ of 84 patients with rheumatoid arthritis who were switched to monthly minodronate from weekly alendronate or risedronate were satisfied and preferred monthly minodronate therapy than weekly bisphosphonate therapy because of the lower burden of frequency. ${ }^{36}$

\section{Pain reduction for minodronate}

The visual analog scale scores for low back pain of the patients with osteoporosis were significantly decreased when daily or weekly bisphosphonates were replaced by monthly minodronate over 6 months. ${ }^{37}$ In the direct comparison with daily alendronate, the use of daily minodronate showed prompter improvement for back pain than daily alendronate. ${ }^{43}$ Another study demonstrated that numerical rating scale (NRS) scores decreased at 2 months after the initiation of monthly minodronate in 113 patients with osteoporosis with low back pain. ${ }^{44}$ They found a significant correlation between the rate of improvement in NRS scores and decreased serum concentration of TRACP-5b.

\section{Safety}

There were no differences in the incidence of gastrointestinal symptoms between the minodronate and placebo groups over 2-3 years ${ }^{29,31}$ or between the daily and monthly regimens of minodronate. ${ }^{30}$ Direct comparison with daily alendronate showed fewer gastrointestinal adverse events in the daily minodronate group than in the daily alendronate group over 24 weeks. ${ }^{43}$ Gastrointestinal symptoms were reduced after 1 month of treatment after switching to monthly minodronate from weekly alendronate or risedronate. ${ }^{37}$
According to the Japanese Adverse Drug Event Report database, the incidence of BRONJ induced by minodronate was the lowest among intravenous or oral bisphosphonates in 2004-2014 in Japan. ${ }^{45}$ To date, no AFF during minodronate therapy has been reported in the English literature.

As bisphosphonates are eliminated from the body through the kidney, the possibility of an adverse effect on renal function should be taken into consideration, especially during long-term use. ${ }^{46}$ However, so far, no abnormality in kidney function has been reported as an adverse event in randomized, controlled studies on the clinical use of minodronate. Our study showed that estimated glomerular filtration rates (e-GFRs) were significantly decreased during the 27-month period of monthly minodronate therapy in female patients with osteoporosis. ${ }^{38}$ However, the rate of decrease was almost the same as was found in the placebo group in the Health Outcomes and Reduced Incidence with Zoledronic Acid Once Yearly (HORIZON) Recurrent Fracture Trial, wherein zoledronate was administered intravenously once a year for 3 years after hip fracture. ${ }^{46}$ It could indicate that the decrease in e-GFR observed during monthly minodronate therapy in our study was probably due to aging. In addition, only 1 case report of acute kidney injury in a patient with stage 3 chronic kidney disease treated by monthly minodronate has been reported to date. ${ }^{47}$

\section{Bone quality assessment for minodronate}

Bisphosphonate administration might result in deterioration of bone microarchitecture due to excessive suppression of bone remodeling. ${ }^{48-50}$ Recent studies have demonstrated that long-term alendronate use induces microdamage, perforation, and weakness of the cancellous bones in the human femoral head. ${ }^{51,52}$ However, optimal doses of minodronate could preserve or even ameliorate bone microarchitecture, as shown in several animal studies. ${ }^{53-55}$ Microdamage caused by minodronate was less than that caused by alendronate, even though there was stronger suppression of bone remodeling by minodronate for 17 months of treatment for ovariectomized cynomolgus monkeys. ${ }^{55}$ In a rat model, minodronate, regardless of the administration regimen (once every 4 weeks or daily), ameliorated worsening bone microarchitectures, including decreased bone mass and trabecular thickness, and increased trabecular separation induced by ovariectomy over 12 months. ${ }^{53,56}$ In a clinical investigation, Ito et $\mathrm{al}^{57}$ demonstrated that daily minodronate increased BMD, geometry, and bone strength of the proximal femur over 12 months in 103 postmenopausal patients with osteoporosis. They concluded 
that minodronate reduced age-related endocortical bone resorption, leading to increased cortical thickness and sustained bone strength. Those previous studies in experimental animal models and humans suggested that both daily and monthly minodronate therapies might not deteriorate bone quality in the short-term period. Monthly minodronate therapy maintained bone trabecular structure, evaluated by the trabecular bone score, which is a new surrogate for trabecular bone microarchitecture assessment, at 1-year monthly minodronate therapy following 2-year daily teriparatide injections in 19 female subjects with osteoporosis. ${ }^{58}$

\section{Discussion}

The R2 side chain of minodronate has a similar chemical structure to that of zoledronate. The side chain of minodronate is a cyclic extension of the aromatic ring of zoledronate. The efficacy of inhibition of osteoclastic bone resorption of minodronate was the same as that of zoledronate and was the strongest among those of the currently available oral bisphosphonates. ${ }^{22}$ Efficacies from the 3-year results of vertebral and hip fracture prevention by zoledronate were reported in the randomized controlled trials in the HORIZON Pivotal Fracture Trial (PFT). ${ }^{59}$ Although the number of subjects in the phase III trial of minodronate for vertebral fracture prevention was lower and the observation period was shorter than that of the HORIZON-PFT, significant risk reduction of minodronate for vertebral fracture was confirmed. Furthermore, increase of spine BMD for minodronate at 3 years $(+10.4 \%)$ reported in the post hoc analysis of phase III trial was greater than that for zoledronate $(+6.7 \%)$ in HORIZONPFT. ${ }^{31,59}$ Considering the lower affinity of minodronate than that of zoledronate to hydroxyapatite, the efficacy of minodronate for hip fracture prevention is expected because of a possibly wider distribution of minodronate than that of zoledronate.

Clinical studies on minodronate for osteoporosis therapy are still scarce. Only 12 papers evaluating BMD or bone turnover changes, where the observation period was $\geq 12$ months, were published to date in the English literature (Table 1). Alendronate, risedronate, and zoledronate have strong efficacies for BMD increase and fracture prevention according to the recent systematic review articles. ${ }^{60-62}$ Efficacies for BMD increase and vertebral fracture prevention by minodronate are similar to that by other bisphosphonates (Table 2). The monthly regimen of minodronate has been available on the market since 2011 . The monthly regimen has noninferiority to the daily regimen in terms of BMD increase, suppression of bone turnover, and incidence of adverse events. ${ }^{29}$ It is well known that the monthly regimen of oral bisphosphonates had several advantages over the daily or weekly regimens regarding adverse events, patient's preference, and adherence. ${ }^{63,64}$ As with other bisphosphonates, patients with osteoporosis were more adherent to the monthly minodronate than to the daily or weekly regimens. ${ }^{35,36,41}$ Longer persistence could be expected for monthly minodronate therapy than for daily or weekly therapy with other bisphosphonates.

In addition to reduction of the incidence of first hip fracture being important, the prevention of a second hip

Table 2 Comparisons of lumbar BMD change and vertebral fracture risk reduction among bisphosphonates over 2-3 years

\begin{tabular}{|c|c|c|c|c|c|c|c|}
\hline BP & Study & $\begin{array}{l}\text { Age } \\
\text { (years) }\end{array}$ & Patients & $\mathbf{n}$ & FU (years) & $\begin{array}{l}\text { Lumbar spine } \\
\text { BMD change }\end{array}$ & RR for VF \\
\hline \multirow{4}{*}{$\begin{array}{l}\text { Minodronate } \\
\text { I mg daily }\end{array}$} & Matsumoto & $55-80$ & Women with $\mathrm{I}-5 \mathrm{VF}$ and BMD $<80 \%$ & MIN 359 & 2 & $N / A$ & $59 \%$ \\
\hline & et $\mathrm{al}^{29}$ & & YAM of lumbar spine & PLC 345 & & & \\
\hline & Hagino & & & MIN 226 & 3 & $+10.4 \%$ & $42 \%$ \\
\hline & et $\mathrm{al}^{28}$ & & & $\mathrm{PLC} / \mathrm{MIN}^{\mathrm{a}} 218$ & & $+6.1 \%$ & \\
\hline \multirow{6}{*}{$\begin{array}{l}\text { Alendronate } 5 \\
\text { or } 10 \mathrm{mg} \text { daily }\end{array}$} & Liberman & $45-80$ & Women with BMD $<2.5$ SD YAM of & ALN 526 & 3 & $+8.8 \%$ greater & $48 \%$ \\
\hline & et $\mathrm{al}^{85}$ & & lumbar spine & PLC 355 & & than PLC & \\
\hline & Black & $55-80$ & Women with existing VF & ALN I,022 & 3 & $+6.2 \%$ greater & $54 \%$ \\
\hline & et $\mathrm{al}^{12,14}$ & & & PLC I,005 & & than PLC & \\
\hline & & & Women without VF and a $T$-score & ALN 819 & 3 & $\mathrm{~N} / \mathrm{A}$ & $16 \%$ \\
\hline & & & $<-2.5$ of femoral neck BMD & PLC 812 & & & \\
\hline Risedronate & Harris & $<85$ & Women with $\geq 2 \mathrm{VF}$ and a $T$-score & RIS 678 & 3 & $+5.4 \%$ & $41 \%$ \\
\hline 2.5 or $5 \mathrm{mg}$ & et $\mathrm{al}^{13}$ & & $<-2$ of lumbar spine BMD & PLC 696 & & $+1.1 \%$ & \\
\hline \multirow[t]{2}{*}{ daily } & Reginster & $\leq 85$ & Women with at least 2 VFs & RIS 346 & 3 & $+5.9 \%$ greater & $49 \%$ \\
\hline & et $\mathrm{al}^{86}$ & & & PLC 344 & & than PLC & \\
\hline Zoledronate & Black et $\mathrm{al}^{59}$ & $65-89$ & Women with a $T$-score $\leq-2.5$ of & ZOL 3,86I & 3 & $+6.7 \%$ greater & $70 \%$ \\
\hline 5 mg yearly & & & femoral neck or $\leq \mathrm{I} .5$ with VF & PLC 3,875 & & than PLC & \\
\hline
\end{tabular}

Note: aPatients in PLC group were administered daily minodronate for 2 years.

Abbreviations: ALN, alendronate; BMD, bone mineral density; BP, bisphosphonate; FU, follow-up period; MIN, minodronate; N/A, not analyzed; PLC, placebo; RIS, risedronate; RR, relative risk reduction rate; VF, vertebral fracture; YAM, young adult mean; ZOL, zoledronate. 
fracture is an urgent issue. Dropout rates of taking antiosteoporosis medicine after experiencing a first hip fracture were extremely high. ${ }^{65-68}$ Those suffering from hip fractures are reluctant to visit the hospital, or once they are institutionalized in nursing facilities, appropriate osteoporosis therapy, especially injection medicines such as teriparatide, denosumab, and zoledronate, is limited in use because of the limitation of insurance. In this regard, monthly minodronate therapy is expected to decrease the dropout rates after hip fracture. Zoledronate and risedronate had favorable results in gaining BMDs after hip fracture; however, only risedronate decreased the incidence of second hip fractures over 3 years. ${ }^{69,70}$ Monthly use of minodronate is also expected to help increase bone mass immediately after hip fracture without any adverse effect on the normal bone healing process and might prevent subsequent contralateral hip fracture. ${ }^{41}$

Long-term results of use of bisphosphonates for patients with osteoporosis have been reported; they were 10 years for alendronate, ${ }^{71} 7$ years for risedronate, ${ }^{72}$ and 9 years for zoledronate. ${ }^{73}$ However, the 3 -year results for BMDs and bone turnover changes, vertebral fracture incidence, and adverse events were from the longest follow-up for minodronate. Only risk reduction for vertebral fractures for daily minodronate therapy over 2 years has been reported to date. ${ }^{28}$ More participants are required to verify the efficacy for hip fracture prevention. This is mainly because of the limitation of the use of minodronate in clinical setting. Currently, minodronate is available only in Japan. Increased hip fracture prevention with minodronate can be expected if minodronate is available worldwide in the near future.

It is reported that bisphosphonates could reduce low back pain in patients with osteoporosis. ${ }^{74,75}$ The mechanisms of action of bisphosphonates for reducing low back pain are not fully elucidated. In a rat model of bone metastasis, zoledronate significantly reduced urinary NTX levels, nociceptive responses, and numbers of osteoclasts in the femoral bone. The antinociceptive responses of zoledronate were positively correlated with the decrease of urinary NTX level. ${ }^{76}$ According to Iwamoto et al, ${ }^{77}$ the decrease of urinary NTX level by daily alendronate therapy for 6 months was significantly correlated with an improvement in pain scores of back pain in 50 elderly women with vertebral fractures. Decrease of osteoclastic activity by inducing cellular apoptosis by bisphosphonates contributes to the prevention of microfractures in the vertebrae or stabilization of the vertebral fracture sites, which are possibly associated with pain reduction. ${ }^{78,79}$ Another unique mechanism of minodronate for pain reduction via the inhibition of the $\mathrm{P} 2 \mathrm{X}(2 / 3)$ receptor may add an advantage over other bisphosphonates. ${ }^{80}$ The $\mathrm{P} 2 \mathrm{X}(2 / 3)$ receptor is thought to be associated with nociceptive, inflammatory, and neuropathic pain. Strong suppression of bone resorption by minodronate and the unique mechanism via the inhibition of the $\mathrm{P} 2 \mathrm{X}(2 / 3)$ receptor might be associated with an improvement in low back pain in patients with osteoporosis.

Although minodronate could preserve bone microarchitecture in animal studies, long-term results on bone quality should be addressed. BRONJ and AFF are both severe complications for long-term use of bisphosphonates due to prolonged suppression of bone turnover and lack of bone remodeling, probably related to the deterioration of bone microarchitecture. The prevalence of BRONJ in patients prescribed with oral bisphosphonates for the treatment of osteoporosis is low, ranging from $0 \%$ to $0.04 \%$, and there is currently no evidence that interruption of bisphosphonate therapy in patients requiring dental extraction reduces the risk of BRONJ. ${ }^{81,82}$ It is reported that the risk of developing BRONJ associated with bisphosphonates increased after 3-4 years of bisphosphonate treatment. ${ }^{83,84}$ The incidence of AFF is also rare, 1.78 per 100,000 for women taking bisphosphonates for less than 2 years; however, it increased to $>100$ per 100,000 for women taking drugs for $\geq 8$ years. ${ }^{62}$ BRONJ and AFF seemed to be less frequent with minodronate than with other bisphosphonates. ${ }^{45}$ The lowest frequency of BRONJ during minodronate therapy is likely due to the shorter period for clinical use compared with that for other bisphosphonates. We should be cautious regarding those adverse events in the future. Furthermore, as with other bisphosphonates, renal function during minodronate therapy, especially for the monthly regimen, should be monitored during long-term osteoporosis therapy.

\section{Conclusion}

Minodronate is the only anti-osteoporosis drug that has been verified as working for risk reduction for vertebral fractures among all the bisphosphonates approved in Japan. Relative risk reduction rates for vertebral fractures for 2-3 years were comparable to alendronate or risedronate. Their incidence of adverse events, especially gastrointestinal disorders, was the same or less than those of other oral bisphosphonates. Moreover, patients were more adherent to the monthly minodronate than to the daily or weekly regimen. However, more clinical studies, especially randomized, controlled, double-blind trials with large numbers of subjects on minodronate, should be conducted to verify the risk reduction for hip fractures. 


\section{Acknowledgment}

The authors declare that no funding was received to conduct the study described in the manuscript or used to assist with the preparation of the manuscript.

\section{Disclosure}

The authors report no conflicts of interest in this work.

\section{References}

1. Kanis JA, McCloskey EV, Johansson H, et al. European guidance for the diagnosis and management of osteoporosis in postmenopausal women. Osteoporos Int. 2013;24(1):23-57.

2. Yoshimura N, Muraki S, Oka H, et al. Prevalence of knee osteoarthritis, lumbar spondylosis and osteoporosis in Japanese men and women: the research on osteoarthritis/osteoporosis against disability study. $J$ Bone Miner Metab. 2009;27(5):620-628.

3. Kwok AW, Leung JC, Chan AY, et al. Prevalence of vertebral fracture in Asian men and women: comparison between Hong Kong, Thailand, Indonesia and Japan. Public Health. 2012;126(6):523-531.

4. Ballane G, Cauley JA, Luckey MM, El-Hajj Fuleihan G. Worldwide prevalence and incidence of osteoporotic vertebral fractures. Osteoporos Int. 2017;28(5):1531-1542.

5. Keene GS, Parker MJ, Pryor GA. Mortality and morbidity after hip fractures. BMJ. 1993;307(6914):1248-1250.

6. Cumming RG, Klineberg R, Katelaris A. Cohort study of risk of institutionalization after hip fractures. Aust N Z J Public Health. 1996;20(6): 579-582.

7. Holt G, Smith R, Duncan K, Hutchison JD, Gregori A, Reid D. Outcome after sequential hip fracture in the elderly. J Bone Joint Surg Am. 2012;94(19):1801-1808

8. Hagino H, Endo N, Harada A, et al. Survey of hip fractures in Japan: recent trends in prevalence and treatment. J Orthop Sci. 2017;22(5): 909-914.

9. Ballane G, Cauley JA, Luckey MM, Fuleihan Gel-H. Secular trends in hip fractures worldwide: opposing trends East versus West. J Bone Miner Res. 2014;29(8):1745-1755.

10. Fisher AA, O'Brien ED, Davis MW. Trends in hip fracture epidemiology in Australia: possible impact of bisphosphonates and hormone replacement therapy. Bone. 2009;45(2):246-253.

11. Alves SM, Economou T, Oliveira C, et al. Osteoporotic hip fractures: bisphosphonates sales and observed turning point in trend. A populationbased retrospective study. Bone. 2013;53(2):430-436.

12. Black DM, Cummings SR, Karpf DB, et al. Randomised trial of effect of alendronate on risk of fracture in women with existing vertebral fractures. Lancet. 1996;348(9041):1535-1541.

13. Harris ST, Watts NB, Genant HK, et al. Effects of risedronate treatment on vertebral and nonvertebral fractures in women with postmenopausal osteoporosis: a randomized controlled trial. Vertebral Efficacy With Risedronate Therapy (VERT) Study Group. JAMA. 1999; 282(14):1344-1352.

14. Black DM, Thompson DE, Bauer DC, et al. Fracture risk reduction with alendronate in women with osteoporosis: the Fracture Intervention Trial. FIT Research Group. J Clin Endocrinol Metab. 2000;85(11): 4118-4124.

15. McClung MR, Geusens P, Miller PD, et al. Effect of risedronate on the risk of hip fracture in elderly women. Hip Intervention Program Study Group. N Engl J Med. 2001;344(5):333-340.

16. Scotti L, Arfé A, Zambon A, Merlino L, Corrao G. Cost-effectiveness of enhancing adherence with oral bisphosphonates treatment in osteoporotic women: an empirical approach based on healthcare utilization databases. BMJ Open. 2014;4(3):e003758.

17. Moriwaki K, Mouri M, Hagino H. Cost-effectiveness analysis of onceyearly injection of zoledronic acid for the treatment of osteoporosis in Japan. Osteoporos Int. 2017;28(6):1939-1950.
18. Chatani Y. [Minodronic acid hydrate as a new therapeutic agent for osteoporosis]. Clin Calcium. 2005;15(1):9-14. Japanese.

19. Kubo T, Shimose S, Matsuo T, Fujimori J, Ochi M. Minodronate for the treatment of osteoporosis. Drugs Today (Barc). 2010;46(1):33-37.

20. Tanishima S, Morio Y. A review of minodronic acid hydrate for the treatment of osteoporosis. Clin Interv Aging. 2013;8:185-189.

21. Rodan GA, Fleisch HA. Bisphosphonates: mechanism of action. J Clin Invest. 1996;97(12):2692-2696.

22. Luckman SP, Hughes DE, Coxon FP, Graham R, Russell G, Rogers MJ. Nitrogen-containing bisphosphonates inhibit the mevalonate pathway and prevent post-translational prenylation of GTP-binding protein, including Ras. J Bone Miner Res. 1998;13(4):581-589.

23. Dunford JE, Thompson K, Coxon FP, et al. Structure-activity relationships for inhibition of farnesyl diphosphate synthase in vitro and inhibition of bone resorption in vivo by nitrogen-containing bisphosphonate. J Pharmacol Exp Ther. 2001;296(2):235-242.

24. Nancollas GH, Tang R, Phipps RJ, et al. Novel insights into actions of bisphosphonates on bone: differences in interactions with hydroxyapatite. Bone. 2006;38(5):617-627.

25. Russell RGG, Watts NB, Ebetino FH, Rogers MJ. Mechanisms of action of bisphosphonates: similarities and differences and their potential influence on clinical efficacy. Osteoporos Int. 2008;19(6):733-759.

26. Ebetino FH, Hogan AM, Sun S, et al. The relationship between the chemistry and biological activity of the bisphosphonates. Bone. 2011; 49(1):20-33

27. Turek J, Ebetino FH, Lundy MW, et al. Bisphosphonate binding affinity affects drug distribution in both intracortical and trabecular bone of rabbits. Calcif Tissue Int. 2012;90(3):202-210.

28. Hagino H, Nishizawa Y, Sone T, et al. A double-blinded head-to-head trial of minodronate and alendronate in women with postmenopausal osteoporosis. Bone. 2009;44(6):1078-1084.

29. Matsumoto T, Hagino H, Shiraki M, et al. Effect on daily oral minodronate on vertebral fractures in Japanese postmenopausal women with established osteoporosis: a randomized placebo-controlled doubleblind study. Osteoporos Int. 2009;20(8):1429-1437.

30. Okazaki R, Hagino H, Ito M, et al. Efficacy and safety of monthly oral minodronate in patients with involutional osteoporosis. Osteoporos Int. 2012;23(6):1737-1745.

31. Hagino H, Shiraki M, Fukunaga M, et al. Three years of treatment with minodronate in patients with postmenopausal osteoporosis. $J$ Bone Miner Metab. 2012;30(4):439-446.

32. Hagino H, Shiraki M, Fukunaga M, et al. Number and severity of prevalent vertebral fractures and the risk of subsequent vertebral fractures in Japanese women with osteoporosis: results from the minodronate trial. J Bone Miner Metab. 2013;31(5):544-550.

33. Ebina K, Noguchi T, Hirao M, Kaneshiro S, Tsukamoto Y, Yoshikawa H. Comparison of the effects of 12 months of monthly minodronate monotherapy and monthly minodronate combination therapy with vitamin $\mathrm{K}_{2}$ or eldecalcitol in patients with primary osteoporosis. J Bone Miner Metab. 2016;34(3):243-250.

34. Kamimura M, Uchiyama S, Nakamura Y, Ikegami S, Mukaiyama K, Kato H. Short-term bisphosphonate treatment reduces serum $25(\mathrm{OH})$ vitamin $\mathrm{D}_{3}$ and alters values of parathyroid hormone, pentosidine, and bone metabolic markers. Ther Clin Risk Manag. 2017;13:161-168.

35. Tanaka S, Yoshida A, Kono S, Ito M. Effectiveness of monotherapy and combined therapy with calcitonin and minodronic acid hydrate, a bisphosphonate, for early treatment in patients with new vertebral fractures: an open-label, randomized, parallel-group study. J Orthop Sci. 2017;22(3):536-541.

36. Ebina K, Noguchi T, Hirao M, et al. Effects of switching weekly alendronate or risedronate to monthly minodronate in patients with rheumatoid arthritis: a 12-month prospective study. Osteoporos Int. 2016;27(1): 351-359.

37. Sakai A, Ikeda S, Okimoto N, et al. Clinical efficacy and treatment persistence of monthly minodronate for osteoporotic patients unsatisfied with, and shifted from, daily or weekly bisphosphonate: the BPMUSASHI study. Osteoporos Int. 2014;25(9):2245-2253. 
38. Ohishi T, Fujita T, Suzuki D, et al. Changes of bone mineral density and serum pentosidine during a 27 -month follow-up of monthly minodronate in osteoporotic patients. Endocr Res. 2017;42(3):232-240.

39. Toda A, Sawada K, Yoshimura A, et al. Effects of minodronate in postmenopausal women with osteoporosis who received prior treatment with raloxifene. Int J Womens Health. 2017;9:821-825.

40. Nakatoh S. Effect of osteoporosis medication on changes in bone mineral density and bone turnover markers after 24-month administration of daily teriparatide: comparison among minodronate, raloxifene, and eldecalcitol. J Bone Miner Metab. 2018;36(2):221-228.

41. Ohishi T, Fujita T, Suzuki D, et al. Initiation of monthly minodronate therapy at an early stage after hip fracture. J Clin Densitom. 2016;19(3): $352-358$.

42. Iwamoto J, Okano H, Furuya T, et al. Patient preference for monthly bisphosphonate versus weekly bisphosphonate in a cluster-randomized, open-label, crossover trial: Minodronate Alendronate/Risedronate Trial in Osteoporosis (MARTO). J Bone Miner Metab. 2016;34(2): 201-208.

43. Yoshioka T, Okimoto N, Okamoto K, Sakai A. A comparative study of the effects of daily minodronate and weekly alendronate on upper gastrointestinal symptoms, bone resorption, and back pain in postmenopausal osteoporosis patients. J Bone Miner Metab. 2013;31(2): 153-160.

44. Fujimoto K, Inage K, Orita S, et al. The nature of osteoporotic back pain without acute vertebral fracture: a prospective multicenter study on the analgesic effect of monthly minodronic acid hydrate. J Orthop Sci. 2017;22(4):613-617.

45. Nakamura M, Umetsu R, Abe J, et al. Analysis of the time-to-onset of osteonecrosis of jaw with bisphosphonate treatment using the data from a spontaneous reporting system of adverse drug events. J Pharm Health Care Sci. 2015;1:34.

46. Miller PD. The kidney and bisphosphonates. Bone. 2011;49(1):77-81.

47. Komada T, Morishita Y, Kitamura M, et al. Acute kidney injury in a patient with nephrotic syndrome due to focal segmental glomerular nephritis induced by a single oral administration of high-dose bisphosphonate (minodronate). Intern Med. 2013;52(12):1383-1387.

48. Mashiba T, Turner $\mathrm{CH}$, Hirao T, et al. Effects of high-dose etidronate treatment on microdamage accumulation and biomechanical properties in beagle bone before occurrence of spontaneous fractures. Bone. 2001;29(3):271-278.

49. Komatsubara S, Mori S, Mashiba T, et al. Suppressed bone turnover by long-term bisphosphonate treatment accumulates microdamage but maintains intrinsic material properties in cortical bone of dog rib. $J$ Bone Miner Res. 2004;19(6):999-1005.

50. Bala Y, Farlay D, Chapurlat RD, Boivin G. Modifications of bone material properties in postmenopausal osteoporotic women long-term treated with alendronate. Eur J Endocrinol. 2011;165(4):647-655.

51. Jin A, Cobb J, Hansen U, et al. The effect of long-term bisphosphonate therapy on trabecular bone strength and microcrack density. Bone Joint Res. 2017;6(10):602-609.

52. Ma S, Goh EL, Jin A, et al. Long-term effects of bisphosphonate therapy: perforations, microcracks and mechanical properties. Sci Rep. 2017;7:43399.

53. Kimoto A, Tanaka M, Nozaki K, et al. Intermittent minodronic acid treatment with sufficient bone resorption inhibition prevents reduction in bone mass and strength in ovariectomized rats with established osteopenia comparable with daily treatment. Bone. 2013;55(1):189-197.

54. Nagira K, Hagino H, Kameyama Y, Teshima R. Effects of minodronate on cortical bone response to mechanical loading in rats. Bone. 2013;53(1):277-283.

55. Yamagami Y, Mashiba T, Iwata K, Tanaka M, Nozaki K, Yamamoto T. Effects of minodronic acid and alendronate on bone remodeling, microdamage accumulation, degree of mineralization and bone mechanical properties in ovariectomized cynomolgus monkeys. Bone. 2013; 54(1):1-7.

56. Tanaka M, Mori H, Kayasuga R, et al. Effect of intermittent and daily regimens of minodronic acid on bone metabolism in an ovariectomized rat model of osteoporosis. Calcif Tissue Int. 2014;95(2):166-173.
57. Ito M, Sone T, Fukunaga M. Effect of minodronic acid hydrate on hip geometry in Japanese women with postmenopausal osteoporosis. J Bone Miner Metab. 2010;28(3):334-341.

58. Miyaoka D, Imanishi Y, Ohara M, et al. Effects of teriparatide and sequential minodronate on lumbar spine bone mineral density and microarchitecture in osteoporosis. Calcif Tissue Int. 2017;101(4):396-403.

59. Black DM, Delmas PD, Eastell R, et al. Once-yearly zoledronic acid for treatment of postmenopausal osteoporosis. $N$ Engl $J$ Med. 2007;356(18):1809-1822.

60. Sanderson J, Martyn-St James M, Stevens J, et al. Clinical effectiveness of bisphosphonates for the prevention of fragility fractures: a systematic review and network meta-analysis. Bone. 2016;89:52-58.

61. Zhou J, Ma X, Wang T, Zhai S. Comparative efficacy of bisphosphonates in short-term fracture prevention for primary osteoporosis: a systematic review with network meta-analyses. Osteoporos Int. 2016; 27(11):3289-3300.

62. Qassem A, Forciea MA, McLean RM, Denberg TD; Clinical Guidelines Committee of the American College of Physicians. Treatment of low bone density or osteoporosis to prevent fractures in men and women: a clinical practice guideline update from the American College of Physicians. Ann Intern Med. 2017;166(11):818-839.

63. Cotté FE, Fardellone P, Mercier F, Gaudin AF, Roux C. Adherence to monthly and weekly oral bisphosphonates in women with osteoporosis. Osteoporos Int. 2010;21(1):145-155.

64. Confavreux CB, Canoui-Poitrine F, Schott AM, Ambrosi V, Tainturier V, Chapurlat RD. Persistence at 1 year of oral antiosteoporotic drugs: a prospective study in a comprehensive health insurance database. Eur $J$ Endocrinol. 2012;166(4):735-741.

65. Panneman MJ, Lips P, Sen SS, Herings RM. Undertreatment with anti-osteoporotic drugs after hospitalization for fracture. Osteoporos Int. 2004;15(2):120-124.

66. Cadarette SM, Katz JN, Brookhart MA, et al. Trends in drug prescribing for osteoporosis after hip fracture, 1995-2004. J Rheumatol. 2008;35(2):319-326.

67. Rabenda V, Vanoverloop J, Fabri V, et al. Low incidence of antiosteoporosis treatment after hip fracture. J Bone Joint Surg Am. 2008; 90(10):2142-2148.

68. Wilk A, Sajjan S, Modi A, Fan CP, Mavros P. Post-fracture pharmacotherapy for women with osteoporotic fracture: analysis of a managed care population in the USA. Osteoporos Int. 2014;25(12):2777-2786.

69. Lyles KW, Colón-Emeric CS, Magaziner JS, et al. Zoledronic acid and clinical fractures and mortality after hip fracture. $N$ Engl $J$ Med. 2007;357(18):1799-1809

70. Osaki M, Tatsuki K, Hashikawa T, et al. Beneficial effect of risedronate for preventing recurrent hip fracture in the elderly Japanese women. Osteoporos Int. 2012;23(2):695-703.

71. Bone HG, Hosking D, Devogelaer JP, et al. Ten years' experience with alendronate for osteoporosis in postmenopausal women. $N$ Engl J Med. 2004;350(12):1189-1199.

72. Mellström DD, Sörensen OH, Goemaere S, Roux C, Johnson TD, Chines AA. Seven years of treatment with risedronate in women with postmenopausal osteoporosis. Calcif Tissue Int. 2004;75(6):462-468.

73. Black DM, Reid IR, Cauley JA, et al. The effect of 6 versus 9 years of zoledronic acid treatment in osteoporosis: a randomized second extension to the HORIZON-Pivotal Fracture Trial (PFT).J Bone Miner Res. 2015;30(5):934-944.

74. Nevitt MC, Thompson DE, Black DM, et al. Effect of alendronate on limited-activity days and bed-disability days caused by back pain in postmenopausal women with existing vertebral fractures. Fracture Intervention Trial Research Group. Arch Intern Med. 2000;160(1):77-85.

75. Kushida K, Fukunaga M, Kishimoto H, et al. A comparison of incidence of vertebral fracture in Japanese patients with involutional osteoporosis treated with risedronate and etidronate: a randomized, double-masked trial. J Bone Miner Metab. 2004;22(5):469-478.

76. Gui Q, Xu C, Li D, Zhuang L, Xia S, Yu S. Urinary N telopeptide levels in predicting the anti-nociceptive responses of zoledronic acid and paclitaxel in an rat model of bone metastases. Mol Med Rep. 2015; 12(3):4243-4249. 
77. Iwamoto J, Takeda T, Ichimura S, Uzawa M. Comparative effects of treatment with etidronate and alendronate on bone resorption, back pain, and activities of daily living in elderly women with vertebral fractures. Keio J Med. 2003;52(4):230-235.

78. Fulfaro F, Casuccio A, Ticozzi C, Ripamonti C. The role of bisphosphonates in the treatment of painful metastatic bone disease: a review of phase III trials. Pain. 1998;78(3):157-169.

79. Bonabello A, Galmozzi MR, Bruzzese T, Zera GP. Analgesic effect of bisphosphonates in mice. Pain. 2001;91(3):269-275.

80. Kakimoto S, Nagakura Y, Tamura S, et al. Minodronic acid, a thirdgeneration bisphosphonate, antagonizes purinergic P2X(2/3) receptor function and exerts an analgesic effect in pain models. Eur $J$ Pharmacol. 2008;589(1-3):98-101.

81. Khan AA, Morrison A, Hanley DA, et al. Diagnosis and management of osteonecrosis of the jaw: a systematic review and international consensus. J Bone Miner Res. 2015;30(1):3-23.

82. Adler RA, El-Hajj Fuleihan G, Bauer DC, et al. Managing osteoporosis in patients on long-term bisphosphonate treatment: report of a task force of the American Society for Bone and Mineral Research. J Bone Miner Res. 2016;31(1):16-35.
83. Ruggiero LS, Dodson TB, Assael LA, et al. American Association of Oral and Maxillofacial Surgeons position paper on bisphosphonaterelated osteonecrosis of jaw - 2009 update. Aust Endod J. 2009;35(3): 119-130.

84. Ruggiero LS, Dodson TB, Fantasia J, et al. American Association of Oral and Maxillofacial Surgeons position paper on medication-related osteonecrosis of the jaw - 2014 update. J Oral Maxillofac Surg. 2014; 72(10):1938-1956.

85. Liberman UA, Weiss SR, Bröll J, et al. Effect of oral alendronate on bone mineral density and the incidence of fractures in postmenopausal osteoporosis. The Alendronate Phase III Osteoporosis Treatment Study Group. N Engl J Med. 1995;333(22):1437-1443.

86. Reginster J, Minne HW, Sorensen OH, et al. Randomized trial of the effects of risedronate on vertebral fractures in women with established postmenopausal osteoporosis. Vertebral Efficacy with Risedronate Therapy (VERT) Study Group. Osteoporos Int. 2000;11(1):83-91.
Therapeutics and Clinical Risk Management

\section{Publish your work in this journal}

Therapeutics and Clinical Risk Management is an international, peerreviewed journal of clinical therapeutics and risk management, focusing on concise rapid reporting of clinical studies in all therapeutic areas, outcomes, safety, and programs for the effective, safe, and sustained use of medicines. This journal is indexed on PubMed Central, CAS,

\section{Dovepress}

EMBase, Scopus and the Elsevier Bibliographic databases. The manuscript management system is completely online and includes a very quick and fair peer-review system, which is all easy to use. Visit http://www.dovepress.com/testimonials.php to read real quotes from published authors.

Submit your manuscript here: http://www.dovepress.com/therapeutics-and-clinical-risk-management-journal 